\title{
Kinerja Gabungan Kelompok Tani dalam Meningkatkan Pendapatan Petani Karet di Kecamatan Banyuasin III, Kabupaten Banyuasin, Provinsi Sumatra Selatan
}

\section{The Performance of Combinated Farmer Groups in Increasing the Income of Rubber Farmers in Banyuasin III District, Banyuasin Regency, South Sumatra Province}

\author{
Sriati $^{1, *)}$, Rismarini $^{2}$, Yunita $^{1}$
}

${ }^{1}$ Fakultas Pertanian, Universitas Sriwijaya, Indralaya 30862, Indonesia

${ }^{2}$ Program Pasca Sarjana, Fakultas Pertanian, Universitas Sriwijaya, Indralaya 30862, Indonesia

${ }^{*}$ E-mail korespondensi: sriati@ unsri.ac.id

Diterima: 30 April 2021 | Disetujui: 8 November 2021 | Publikasi Online: 3 Desember 2021

\begin{abstract}
One such efforts to develop rubber business by forming a farmer group. This study aims to: (1) measure the level of performance the combined farmer group and the rubber farmer group, (2) measure the behavior rubber farmer, (3) calculate the production and income, (4) analyze the relationship the combined performance of the farmer group and the rubber farmer group with the behavior of rubber farmers, (5) analyzing the relationship behavior with production and income of rubber farmers. Research in the District Banyuasin III. This research method uses survey methods. Data from research and interviews made qualitatively presented in tabulation, mathematical calculations explained descriptively and Spearman Rank correlation analysis. Respondents are members of rubber farmers. The results of the study (1) the level of performance the combined farmer group high (98.00\%) and the farmer group high (93.73\%), (2) the behavior of farmers high (93.26\%), (3) the average production (5,008 tons/year/cultivated) and average income of (Rp.33,600,059,122,-year/arable), (4) there is a significant relationship the performance of Gapoktan and Poktan with the behavior of rubber farmers, the value of Spearman Rank correlation coefficient 0.340 and $0.374 \alpha 0.01$, (5) there is no relationship behavior and production and income of rubber farmers with Spearman Rank correlation coefficient -0.032 and -0.070.
\end{abstract}

Keywords: Farmers group, income, performance, rubber farmer

\begin{abstract}
ABSTRAK
Salah satu upaya mengembangkan usaha karet dengan pembentukan gabungan kelompok tani. Penelitian bertujuan untuk: (1) mengukur tingkat kinerja gabungan kelompok tani dan kinerja kelompok tani usahatani petani karet, (2) mengukur perilaku petani karet, (3) menghitung produksi dan pendapatan petani karet, (4) menganalisis hubungan kinerja gabungan kelompok tani dan kinerja kelompok tani dengan perilaku petani karet, (5) menganalisis hubungan perilaku dengan produksi dan pendapatan petani karet. Lokasi penelitian di Kecamatan Banyuasin III, yang dipilih secara purposive. Metode penelitian ini menggunakan metode survey. Data hasil penelitian dan wawancara disajikan dalam tabel, perhitungan secara matematis dijelaskan secara deskriptif dan analisis korelasi Rank Spearman. Responden anggota kelompok petani karet. Hasil penelitian (1) tingkat kinerja gabungan kelompok tani tinggi (98,00\%) dan kinerja kelompok tani tinggi (93,73\%), (2) perilaku petani tinggi $(93,26 \%)$, (3) produksi rata-rata $(5,008$ ton/tahun/garapan) dan pendapatan rata-rata sebesar (Rp. 33.600.059,122/tahun/garapan), (4) terdapat hubungan signifikan antara kinerja gapoktan dan poktan dengan perilaku petani karet, nilai koefisien korelasi Rank Spearman 0,340 dan 0,374, dan (5) tidak terdapat hubungan antara perilaku dengan produksi dan pendapatan petani karet dengan nilai koefisien korelasi Rank Spearman 0,032 dan $-0,070$.
\end{abstract}

Kata kunci: Kelompok tani, kinerja, pendapatan, petani karet

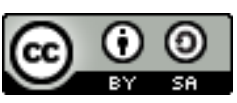

Content from this work may be used under the terms of the Creative Commons Attribution-ShareAlike 4.0 International. Any further distribution of this work must maintain attribution to the author(s) and the title of the work, journal citation and DOI.

Published under Department of Communication and Community Development Science, IPB University and in association with Perhimpunan Ahli Penyuluhan Pembangunan Indonesia.

E-ISSN: 2442-4110 | P-ISSN: 1858-2664 


\section{PENDAHULUAN}

Karet adalah komoditas perkebunan dengan nilai ekonomi tinggi. Karet merupakan bahan baku yang diproses dari penggumpalan getah cair dari tanaman karet (lateks), yang dapat berbentuk-bongkahan (kotak), lembaran karet (sheet), atau karet remah (crumb rubber) (Tampubolon, et al 2013). Upaya untuk mengembangkan usaha karet rakyat dilakukan dengan pembentukan Kelompok Tani (Poktan) yang dibina oleh PPL yang selanjutnya diarahkan membentuk wadah yang lebih besar yaitu Gabungan Kelompok Tani (Gapoktan). Gapoktan diharapkan dapat berperan sebagai wahana kerjasama anggotanya dengan pihak lain serta sumber informasi, teknologi, dan permodalan. Gapoktan diharapkan akan menjadikan Kelembagaan Petani yang kokoh dan mandiri serta berdaya saing, sehingga Gapoktan dapat berperan dalam meningkatkan pendapatan petani karet. Kabupaten Banyuasin merupakan salah satu area yang memiliki banyak perkebunan karet dan menerapkan sistem ini.

Berdasarkan data dari BPS (2017), Perkebunan karet Kabupaten Banyuasin didominasi perkebunan rakyat yaitu 91.004 hektar, dengan produksi 93.777 ton. Sementara perkebunan negara luas panennya 7.298 hektar dengan produksi 24.220 ton, dan perkebunan swasta luasnya 5.318 hektar, dengan produksi 17.017 ton. Di Kabupaten Banyuasin, Kecamatan Banyuasin III memiliki luas panen terbesar yaitu 16.191 hektar, dengan produksi 16.666 ton, pada tahun 2017.

Penelitian terdahulu tentang Pengaruh Keberadaan Gapoktan terhadap Pendapatan Petani dan Perubahan Tutupan Lahan di Hutan Kemasyarakatan telah dilakukan oleh Safe'i, et al (2018). Hasil penelitian menunjukkan terdapat peningkatan pendapatan anggota Gapoktan, yaitu pendapatan rata-rata dari Rp. 31.416.66/ha/tahun menjadi Rp. 37.054.042/ha/tahun di Gapoktan Sinar Mulya, dan dari ratarata Rp. 25.473.684/ha/tahun menjadi rata-rata Rp. 29.368.421/ha/tahun di Gapoktan Beringin Jaya. Pada ke dua Gapoktan juga terjadi perubahan tutupan lahan di areal kerja, yaitu areal pertanian dan lahan terbuka semakin meluas. Penelitian serupa juga dilakukan Muhammad (2016), yang menyimpulkan bahwa ada hubungan positif signifikan yang cukup kuat $\left(\mathrm{Rs}=0,530^{* *}\right)$ antara tingkat pendapatan dengan kinerja Gapoktan dalam program PUAP.

Berdasarkan uraian tersebut, peneliti ingin mengetahui bagaimana kinerja Gapoktan dalam meningkatkan pendapatan petani karet di Kecamatan Banyuasin III, Kabupaten Banyuasin. Secara rinci tujuan penelitian meliputi: (1) mengukur tingkat kinerja Gapoktan perilaku petani dalam kegiatan usahatani petani karet, (2) menghitung produksi dan pendapatan petani karet, (3) menganalis hubungan kinerja Gapoktan dan perilaku petani karet, dengan produksi dan pendapatan.

\section{METODE}

Penelitian dilakukan dengan metode eksplanatori survei di Kecamatan Banyuasin III Kabupaten Banyuasin, dengan pertimbangan Kecamatan Banyuasin III mempunyai lahan karet terluas di Kabupaten Banyuasin. Data dikumpulkan pada bulan September 2019-Agustus 2020. Data dan fakta lapangan dikumpulkan secara langsung melalui kuisioner dan wawancara, secara tatap muka (face to face contact) antara peneliti dengan responden) (Ruslan, 2006). Metode penarikan contoh menggunakan sampling bertahap (multistage sampling). Sampling bertahap merupakan teknik sampling dengan memadukan berbagai teknik sampling probabilitas yang ada (Sriati, 2012). Kecamatan Banyuasin III terdapat tujuh Wilayah Kerja Penyuluhan Pertanian (WKPP). Dari setiap WKPP diambil 2 gapoktan, selanjutnya dari setiap gapoktan diambil 2 dan dari setiap poktan diambil 3 anggota poktan, sehingga jumlah respondennya 84 petani karet, yang diambil dari 28 poktan dan 14 gapoktan.

Data penelitian disajikan dalam tabel, dianalisis dan diuraikankan secara deskriptif. Uji korelasi Rank Spearman digunakan untuk menganalisis hubungan antar variabel. Tingkat kinerja gapoktan, kinerja poktan dan perilaku petani karet diukur dengan skala Likert, kemudian dikatagorikan melalui perhitungan interval kelas (Ridwan dan Akdon, 2007). Tingkat kinerja gapoktan diukur berdasarkan fungsinya terdiri atas 5 indikator yaitu: (1) unit usaha sarana dan prasarana produksi, (2) unit usahatani/produksi, (3) unit usaha pengolahan, (4) unit usaha pemasaran dan (5) unit usaha keuangan mikro. Setiap indikator ada 3 pertanyaan sehingga ada 15 pertanyaan. Untuk kinerja poktan diukur berdasarkan 3 indikator yaitu: (1) kelas belajar, (2) wahana kerjasama, dan (3) unit produksi, dan setiap indikator ada 3 pertanyaan, sehingga ada 9 pertanyaan. Selanjutnya perilaku petani diukur dari 3 indikator yaitu (1) pengetahuan, (2) sikap dan (3) keterampilan. Setiap indikator ada 5 aspek, yang masing-masing ada 3 pertanyaan, sehingga utk perilaku petani ada 45 pertanyaan. Adapun uraian variabel dan indikatornya seperti yang tercantum pada Tabel 1. 
Tabel 1. Indikator Variabel Kinerja Gapoktan, Kinerja Poktan dan Perilaku

\begin{tabular}{llcc}
\hline \multicolumn{1}{c}{ Variabel } & \multicolumn{1}{c}{ Indikator } & Pertanyaan & Skor maks. \\
\hline \multirow{2}{*}{ Kinerja } & 1. Unit Usaha Sarana dan Prasarana Produksi & $1-3$ & 9 \\
Gapoktan & 2. Unit Usahatani/ Produksi & $4-6$ & 9 \\
& 3. Unit Usaha Pengolahan & $7-9$ & 9 \\
& 4. Unit Usaha Pemasaran & $10-12$ & 9 \\
& 5. Unit Usaha Keuangan Mikro & $13-15$ & 9 \\
Kinerja & 1. Kelas Belajar & $1-3$ & 9 \\
Poktan & 2. Wahana Kerjasama & $4-6$ & 9 \\
& 3. Unit Produksi & $7-9$ & 9 \\
\multirow{2}{*}{ Perilaku } & 1. Pengetahuan & $1-15$ & 45 \\
& 2. Sikap & $16-30$ & 45 \\
& 3. Keterampilan & $31-45$ & 45 \\
\hline
\end{tabular}

Selanjutnya untuk setiap pertanyaan diukur dengan pemberian skor 1, 2 dan 3 yang merepresentasikan capaian rendah, sedang, dan tinggi, sehingga skor maksimum tiap indikator kenerja Gapoktan dan poktan adalah 9, dan indikator perilaku skor maksimum 45. Total jawaban terhadap indikator/ variabel dikatagorikan dalam 3 tingkatan/kriteria berdasarkan rumus interval kelas, dan nilai kriteria setiap indikator diperlihatkan pada Tabel 2.

Tabel 2. Nilai Interval Kelas untuk Mengukur Variabel Kinerja Gapoktan, Kinerja Poktan dan Perilaku

\begin{tabular}{|c|c|c|c|c|c|c|c|c|c|c|}
\hline No & & Variabel /Indikator & $\begin{array}{l}\text { Item } \\
\text { Pert. }\end{array}$ & Min & Max & NR & PI & \multicolumn{3}{|c|}{ Kriterian } \\
\hline \multirow{7}{*}{\multicolumn{2}{|c|}{$\begin{aligned} & \mathrm{K} \\
& \mathrm{a}\end{aligned}$}} & eria Ganoktan & & & & & & & & \\
\hline & & 1erja Uароктап & 15 & 15 & 45 & 30 & 10 & $10-25$ & $26-35$ & $36-45$ \\
\hline & & $\begin{array}{l}\text { Unit Usaha Sarana dan } \\
\text { Prasarana Produksi }\end{array}$ & 3 & 3 & 9 & 6 & 2 & $3-5$ & $6-7$ & $8-9$ \\
\hline & & $\begin{array}{l}\text { Unit Usahatani/ } \\
\text { Produksi }\end{array}$ & 3 & 3 & 9 & 6 & 2 & $3-5$ & 6-7 & $8-9$ \\
\hline & & Unit Usaha Pengolahan & 3 & 3 & 9 & 6 & 2 & $3-5$ & $6-7$ & $8-9$ \\
\hline & & Unit Usaha Pemasaran & 3 & 3 & 9 & 6 & 2 & $3-5$ & 6-7 & $8-9$ \\
\hline & & $\begin{array}{l}\text { Unit Usaha Keuangan } \\
\text { Mikro }\end{array}$ & 3 & 3 & 9 & 6 & 2 & $3-5$ & 6-7 & $8-9$ \\
\hline \multirow{4}{*}{\multicolumn{2}{|c|}{ 2. $\begin{array}{r}\mathrm{K} \\
\mathrm{a} \\
\mathrm{b} \\
\mathrm{b}\end{array}$}} & herja Poktan & 9 & 9 & 27 & 18 & 6 & $9-15$ & $16-21$ & $22-27$ \\
\hline & & Kelas Belajar & 3 & 3 & 9 & 6 & 2 & $3-5$ & 6-7 & $8-9$ \\
\hline & & Wahana Kerjasama & 3 & 3 & 9 & 6 & 2 & $3-5$ & $6-7$ & $8-9$ \\
\hline & & Unit Produksi & 3 & 3 & 9 & 6 & 2 & $3-5$ & $6-7$ & $8-9$ \\
\hline \multirow[t]{4}{*}{3.} & & ilaku & 45 & 45 & 135 & 90 & 30 & $45-74$ & $75-104$ & $105-135$ \\
\hline & & Pengetahuan & 15 & 15 & 45 & 30 & 10 & $15-25$ & $26-35$ & $36-45$ \\
\hline & & Sikap & 15 & 15 & 45 & 30 & 10 & $15-25$ & $26-35$ & $36-45$ \\
\hline & & Keterampilan & 15 & 15 & 45 & 30 & 10 & $15-25$ & $26-35$ & $36-45$ \\
\hline
\end{tabular}

Untuk menjawab tujuan kedua, yaitu menghitung produksi dan pendapatan petani karet anggota kelompok tani, digunakan analisis kuantitatif usahatani. Analisis pendapatan, dihitung dengan rumus: (Soekartawi, 2002).

1. Total biaya $(\mathrm{TC})=$ Biaya Tetap $(\mathrm{FC})+$ Biaya Variabel $(\mathrm{VC})$

2. Total Penerimaan $(\mathrm{TR})=$ Produksi $(\mathrm{Y}) \mathrm{x}$ Harga $(\mathrm{Py})$

3. Pendapatan $(\mathrm{Pd})=$ Total Penerimaan $(\mathrm{TR})$-Total Biaya $(\mathrm{TC})$

Untuk menjawab tujuan ketiga, yaitu untuk menganalisis hubungan antar variabel digunakan Uji Korelasi Rank Spearman. Metode ini diperlukan guna mengukur tingkat keeratan hubungan dua peubah berpasangan, yang pengukurannya dengan skala nominal atau ordinal, yang tidak memungkinkan menggunakan statistika parametrik (Sugiyono, 2009). 


\section{HASIL DAN PEMBAHASAN}

\section{Karakteristik Responden}

Responden penelitian adalah 84 petani karet yang merupakan anggota kelompok tani dari 14 Gapoktan di Kecamatan Banyuasin III. Karakteristik responden meliputi umur, pendidikan, jumlah tanggungan, luas lahan garapan, dan lama berusahatani. Hasil penelitian menunjukkan umur responden berkisar 2563 tahun dengan didominasi umur 38-50 tahun berjumlah 63,10\%. Pendidikan responden menyebar dari SD hingga S1 dengan jumlah terbanyak SMA yaitu 39 orang (46,43\%). Lama berusaha tani petani karet berkisar 10-40 tahun, didominasi 10-20 tahun yaitu 37 orang (44,05\%). Tanggungan keluarga Responden berkisar 1-6 orang, dan 60 orang $(71,43 \%)$ memiliki 1-2 orang tangguan. Luas lahan responden bervariasi dari 1,5-3 $\mathrm{Ha}$, rata-rata $2,07 \mathrm{Ha}$, dan 72 orang $(85,72 \%)$ memiliki lahan $2 \mathrm{Ha}$.

\section{Kinerja Gabungan Kelompok Tani (Gapoktan) Petani Karet}

Tingkat Kinerja Gapoktan diukur berdasarkan fungsinya, yaitu unit usahatani/produksi, unit usaha sarana dan prasarana produksi, unit usaha pengolahan, unit usaha pemasaran, dan unit usaha keuangan mikro (simpan pinjam). Hasil pengukuran setiap indikator tingkat kinerja Gapoktan diperlihatkan pada Tabel 3.

Tabel 3. Skor Tingkat Kinerja Gapoktan

\begin{tabular}{lcccc}
\hline \multicolumn{1}{c}{ Indikator } & Skor Total** & Rata-rata & Capaian $(\%)$ & Kriteria Capaian \\
\hline 1. Unit Usaha Sarana dan & 736 & 8,77 & 97,35 & Tinggi \\
Prasarana Produksi & 742 & 8,82 & 98,14 & Tinggi \\
2. Unit Usahatani/ Produksi & 744 & 8,84 & 98,40 & Tinggi \\
3. Unit Usaha Pengolahan & 746 & 8,88 & 98,66 & Tinggi \\
4. Unit Usaha Pemasaran & 737 & 8,78 & 97,48 & Tinggi \\
5. Unit Usaha Keuangan Mikro & 3.705 & 44,09 & 98,00 & Tinggi \\
\hline Skor Total & & & \\
\hline Keterangan: *Capaian (\%) diukur skor total/skor ideal & & & \\
**Skor Ideal tiap indikator = 3 3 8 84=756 & & &
\end{tabular}

Dari Tabel 3 dapat diketahui bahwa tingkat kinerja gapoktan termasuk kriteria tinggi, skor total 3.705 rata-rata 44,05 (capaian 98,00\%). Dilihat dari setiap indikator tampak bahwa semua indikator kinerja gapoktan termasuk kriteria tinggi. Kuesioner pada variabel kinerja gapoktan terdiri dari 15 item pernyataan. Deskripsi terinci tentang jawaban responden terhadap setiap item pertanyaan tersebut diperlihatkan pada Tabel 4.

Tabel 4. Skor Tingkat Kinerja Gapoktan

\begin{tabular}{|c|c|c|c|c|c|c|c|}
\hline \multirow{2}{*}{$\begin{array}{c}\text { Item } \\
\text { Pertanyaan }\end{array}$} & \multicolumn{3}{|c|}{ Jawaban Responden } & \multirow{2}{*}{ Skor Total ${ }^{* *}$} & \multirow{2}{*}{ Rata - rata } & \multirow{2}{*}{ Capaian $(\%)^{*}$} & \multirow{2}{*}{$\begin{array}{l}\text { Kriteria } \\
\text { Capaian }\end{array}$} \\
\hline & 1 & 2 & 3 & & & & \\
\hline 1 & 0 & 12 & 72 & 240 & 2,85 & 95,23 & Tinggi \\
\hline 2 & 0 & 6 & 78 & 246 & 2,92 & 97,61 & Tinggi \\
\hline 3 & 0 & 0 & 84 & 252 & 3,00 & 100 & Tinggi \\
\hline Jumlah & & & & 736 & 8,77 & $\mathbf{9 7 , 3 5}$ & Tinggi \\
\hline 4 & 0 & 11 & 73 & 241 & 2,86 & 95,63 & Tinggi \\
\hline 5 & 0 & 3 & 81 & 249 & 2,96 & 98,80 & Tinggi \\
\hline 6 & 0 & 0 & 84 & 252 & 3,00 & 100 & Tinggi \\
\hline Jumlah & & & & 742 & 8,82 & 98,14 & Tinggi \\
\hline 7 & 0 & 5 & 79 & 247 & 2,94 & 98 & Tinggi \\
\hline 8 & 0 & 6 & 78 & 246 & 2,92 & 97,61 & Tinggi \\
\hline 9 & 0 & 1 & 83 & 251 & 2,98 & 99,60 & Tinggi \\
\hline Jumlah & & & & 744 & 8,84 & 98,40 & Tinggi \\
\hline 10 & 0 & 10 & 74 & 242 & 2,88 & 96 & Tinggi \\
\hline 11 & 0 & 0 & 84 & 252 & 3,00 & 100 & Tinggi \\
\hline 12 & 0 & 0 & 84 & 252 & 3,00 & 100 & Tinggi \\
\hline Jumlah & & & & 746 & $\mathbf{8 , 8 8}$ & 98,66 & Tinggi \\
\hline 13 & 0 & 6 & 78 & 246 & 2,93 & 97,61 & Tinggi \\
\hline 14 & 0 & 2 & 82 & 250 & 2,98 & 99,20 & Tinggi \\
\hline
\end{tabular}




\begin{tabular}{|c|c|c|c|c|c|c|c|}
\hline \multirow{2}{*}{$\begin{array}{c}\text { Item } \\
\text { Pertanyaan } \\
\end{array}$} & \multicolumn{3}{|c|}{ Jawaban Responden } & \multirow{2}{*}{ Skor Total** } & \multirow[b]{2}{*}{ Rata - rata } & \multirow{2}{*}{ Capaian $(\%)^{*}$} & \multirow{2}{*}{$\begin{array}{l}\text { Kriteria } \\
\text { Capaian }\end{array}$} \\
\hline & 1 & 2 & 3 & & & & \\
\hline 15 & 0 & 11 & 72 & 241 & 2,87 & 95,63 & Tinggi \\
\hline Jumlah & & & & 737 & 8,78 & 97,48 & Tinggi \\
\hline Skor Total & $\mathbf{0}$ & 73 & 1.186 & 3.705 & 44,09 & 98,00 & Tinggi \\
\hline
\end{tabular}

Keterangan: *Capaian (\%) diukur skor total/skor ideal

**Skor Ideal tiap indikator $=3$ x 3 x $84=756$

Kriteria Capaian mengacu pada Tabel 2

Berdasarkan Tabel 3 dan 4 diketahui pengukuran tingkat kinerja gapoktan termasuk kriteria tinggi, baik secara total maupun setiap indikatornya. Indikator pertama yaitu mengenai unit usaha sarana dan prasarana produksi memperoleh skor 736 , dengan rata-rata 8,77 dimana capaian 97,35\% tergolong kriteria tinggi. Pada indikator ini juga gapoktan mampu bekerja sama dengan pihak penyedia sarana prasarana produksi. Hal ini terbukti berdasarkan hasil wawancara penelitian bahwa Dinas Perkebunan Kabupaten Banyuasin memberikan bantuan langsung kepada petani karet berupa alat-alat sadap, gedung untuk pelelangan karet, mobiler dan alat pasca panen.

Indikator kedua yaitu unit usahatani/produksi memperoleh skor 742 rata-rata 8,82 (capaian 98,14\%) tergolong kriteria tinggi. Indikator ketiga yaitu unit usaha pengolahan (item 7-9) memperoleh 744 ratarata 8,84 (capaian 98,40\%) tergolong dalam kriteria tinggi. Indikator keempat yaitu unit usaha pemasaran memperoleh skor 746 dengan rata-rata 8,88 (capaian 98,66 \%) tergolong kriteria tinggi. Artinya kinerja gapoktan sudah maksimal hal ini dapat dilihat pada item pertanyaan 12 yang mana gapoktan dapat menjalin hubungan dengan pelaku pasar dengan rata-rata 3,00 dalam kriteria tinggi. Ini menunjukkan anggota gapoktan petani karet mampu menganalisis dan merencanakan kebutuhan pasar agar karet tidak jatuh pada pasar lelang. Indikator kelima unit usaha keuangan mikro memperoleh skor 737 dengan rata-rata 8,78 (Capaian 97,48\%) dengan kriteria tinggi. Artinya kinerja gapoktan sudah maksimal hal ini dapat dilihat karena keanggotaan dari gapoktan petani karet ini telah mampu menabung dari pendapatan mereka. Setiap anggota gapoktan mampu menabung sekitar Rp 10.000,00 - Rp 50.000,00 sebagai cadangan untuk memenuhi kebutuhan khusus yang tidak terduga.

Penelitian ini didukung Indrawati (2016), yang menyatakan bahwa fungsi Gapoktan Pojok kulon yaitu: a) memfasilitasi kredit melalui simpan pinjan musiman dan bulanan untuk anggota Gapoktan, b) memperbaiki sistem penjualan dan pembelian beruba gabah dan beras, dengan sistem tunda penjualan dan dengan harga murah, c) memfasilitasi sewa alat pertanian dan d) memberantas hama dengan berkelompok. Studi ini juga sama dengan Sihotang et al., (2019) menunjukkan bahwa melaui analisis CSI anggota kelompok merasa puas terhadap kinerja pelayananan Gapoktan. Rerata tingkat kepentingan pada semua aspek pada indikator mempunyai nilai 4,07 dengan tingkat kepuasan rata-rata semua dimensi pada semua indikator adalah3,51. Berdasarkan pengukuran CSI kepuasan anggota termasuk kriteria puas, yaitu bernilai 0,70 (berada pada rentang 0,61-0,80). Penelitian ini juga sejalan dengan Sriati,et al (2017), yang menyatakan : efektivitas Gapoktan dalam Proram LPDM tinggi $(79,92 \%)$, partisipasi petani dalam program LDPM tergolong sedang $(57,04 \%)$, dan (3) terdapat hubungan positif signifikan $(\mathrm{Rs}=0,479)$ antara partisipasi petani dengan efektivitas Gapoktan.

Penelitian ini berbeda dengan Demmallino, et al (2018), yang menyatakan (1) Pelaksanaan fungsi Gapoktan Pottanae baru setengah dari fungsinya yaitu sebagai unit penyedia sarana dan prasarana produksi pertanian. Sementara fungsi sebagai unit usahatani, unit pemasaran, unit pengolahan, dan unit keuangan mikro atau simpan pinjam belum terlaksana. Disebutkan pula bahwa efektivitas kinerja Gapoktan Pottanae tidak efektif, yakni hanya 17,20\%. Kebutuhan anggota belum bisa dipenuhi Gapoktan, baik kebutuhan alat mesin pertanian dan permodalan usahatani, jaminan kualitas, kuantitas, dan kontinuitas produk, nilai tambah produk, maupun belum ada jaminan pasar serta belum adanya kemandirian usaha bagi anggota.

Berbeda dengan penelitian Hadi, et al (2019), tentang kelompok yang menerapkan sistem pertanian organik. Disebutkan bahwa kelompok tani cukup berhasil dalam mendorong anggotanya untuk menerapkan sistem pertanian organik. Hal ini dilihat dari: 1) pengetahuan dan peran kelompok tani untuk memberi arahan tentang organic farming masih kurang (44\%), 2) tingkat kesadaran petani rendah, kurang sabar dan tidak tidak ingin susah $(12 \%)$, 3) informasi tentang pertanian organik dari PPL setempat masih kurang (24\%), dan 4) belum ada jaminan pasar produk organik para petani (20\%). Tingkat partisipasi petani dalam penerapan budidaya padi organik dipengaruhi oleh persepsinya 
terhadap jaminan harga. Penelitian juga berbeda dengan Fatchiya \& Hernanda (2015) yang menyebutkan bahwa kinerja penyuluh di OKU Selatan cukup baik, yang ditunjukkan oleh kapasitas penyuluh dalam persiapan dan pelaksanaan kegiatan penyuluhan. Namun dalam evaluasi penyuluhan masih kurang, sehingga diperlukan dalam kegiatan evaluasi secara berkelanjutan. Di Kecamatan Banyuasin III kinerja gapoktan termasuk kriteria tinggi. Hal ini menunjukkan bahwa keberlangsungan Gapoktan memerlukan peran penyuluh.

\section{Kinerja Kelompok Tani Petani Karet (Poktan)}

Tingkat kinerja kelompok tani diukur dengan penjumlahan semua skor indikator kelas belajar, wahana kerjasama dan unit produksi. Skor rata-rata setiap indikator tingkat kinerja kelompok ditampilkan pada Tabel 5.

Tabel 5. Skor Tingkat Kinerja Kelompok tani

\begin{tabular}{lcccc}
\hline \multicolumn{1}{c}{ Indikator } & Skor Total** & Rata - rata & Capaian $(\%)$ & Kriteria Capaian \\
\hline 1. Kelas Belajar & 695 & 8,26 & 91,92 & Tinggi \\
2. Wahana Kerjasama & 722 & 8,58 & 95,49 & Tinggi \\
3. Unit Produksi & 709 & 8,43 & 93,78 & Tinggi \\
\hline Skor Total & 2.126 & 25,27 & 93,73 & Tinggi \\
\hline Keterangan: *Capaian $(\%)$ diukur skor total/skor ideal & & & \\
**Skor Ideal tiap indikator $=3 \times 3 \times 84=756$ & & & \\
$\quad$ Kriteria Capaian mengacu pada Tabel 2 & & &
\end{tabular}

Tabel 5 menunjukkan bahwa tingkat kinerja kelompok tani termasuk kriteria tinggi dengan skor total 2.126 rata-rata 25,27 (capaian 93,73\%). Bila dilihat dari setiap indikator tampak bahwa semua indikator kinerja poktan termasuk kriteria tinggi. Kuesioner pada variabel kinerja poktan terdiri dari 9 item pernyataan. Berikut ini deskripsi terinci tentang jawaban responden terhadap setiap item pertanyaan tersebut diperlihatkan pada Tabel 6.

Tabel 6. Skor Tingkat Kinerja Poktan

\begin{tabular}{|c|c|c|c|c|c|c|c|}
\hline \multirow{2}{*}{$\begin{array}{c}\text { Item } \\
\text { Pertanyaan }\end{array}$} & \multicolumn{3}{|c|}{ Jawaban Responden } & \multirow{2}{*}{ Skor Total** } & \multirow{2}{*}{$\begin{array}{c}\text { Rata - } \\
\text { rata }\end{array}$} & \multirow{2}{*}{ Capaian $(\%)^{*}$} & \multirow{2}{*}{$\begin{array}{l}\text { Kriteria } \\
\text { Capaian }\end{array}$} \\
\hline & 1 & 2 & 3 & & & & \\
\hline 1 & 0 & 24 & 60 & 228 & 2,71 & 90,47 & Tinggi \\
\hline 2 & 0 & 6 & 78 & 246 & 2,92 & 97,61 & Tinggi \\
\hline 3 & 0 & 31 & 53 & 221 & 2,63 & 87,61 & Tinggi \\
\hline Jumlah & & & & 695 & 8,26 & 91,92 & Tinggi \\
\hline 4 & 0 & 27 & 57 & 225 & 2,67 & 89,28 & Tinggi \\
\hline 5 & 0 & 4 & 80 & 248 & 2,95 & 98,41 & Tinggi \\
\hline 6 & 0 & 3 & 81 & 249 & 2,96 & 98,80 & Tinggi \\
\hline Jumlah & & & & 722 & 8,58 & 95,49 & Tinggi \\
\hline 7 & 0 & 29 & 55 & 223 & 2,65 & 88,49 & Tinggi \\
\hline 8 & 0 & 0 & 84 & 252 & 3,00 & 100 & Tinggi \\
\hline 9 & 0 & 9 & 75 & 234 & 2,78 & 92,85 & Tinggi \\
\hline Jumlah & & & & 709 & 8,43 & 93,78 & Tinggi \\
\hline Skor Total & 0 & 133 & 623 & 2.126 & 25,27 & 93,73 & Tinggi \\
\hline
\end{tabular}

Dari Tabel 6 dapat dilihat bahwa indikator pertama, kelas belajar memperoleh skor 695 dengan rata-rata 8,26 (caaian 91,92\%), tergolong kriteria tinggi. Artinya kinerja poktan sudah mencapai hasil yang maksimal karena anggota poktan sudah membuat wahana belajar untuk berusaha menggali ilmu, selain itu peran PPL sangat menentukan kegiatan belajar. Indikator kedua yaitu wadah kerja sama memperoleh skor 722 rata-rata 8,58 (capaian 95,49\%), tergolong kriteria tinggi. Artinya kinerja poktan sudah maksimal hal ini terbukti anggota poktan dapat mengatur dan melaksanakan pembagian tugas/kerja diantara anggota sesuai dengan kesepakatan bersama. Indikator ketiga yaitu unit produksi memperoleh 
skor 709 dengan rata-rata 8,43 (Capaian 93,78 \%) tergolong dalam kriteria tinggi. Artinya kinerja poktan sudah maksimal alasannya anggota poktan dapat memutuskan pengembangan produksi yang menguntungkan berdasarkan sumberdaya yang ada, yaitu teknologi, modal dan sarana roduksi.

Hasil penelitian ini berbeda dengan Mujiburrahmad (2014) yang menyatakan tingkat kinerja penyuluh pertanian di Kabupaten Pidie relatif rendah. Tingkat kinerja penyuluh berkorelasi dengan (1) Faktor karakteristik internal, yaitu jumlah kelompok binaan dan waktu kerja, (2) Faktor karakteristik eksternal yaitu: keadaan lingkungan kerja dan dukungan adminitrasi (3) Faktor kompetensi tugas penyuluh yakni: kemampuan komunikasi dan bekerjasama serta penerapan prinsip belajar orang dewasa.

Penelitian ini berbeda dengan Jaya, et al (2017) yang menyatakan (a) dalam berusaha tani padi kelompok tani masih belum bisa meningkatkan keberdayaannya, (b) terhadap tingkat keberdayaan kelompok tani dipengaruhi secara langsung oleh pelaksanaan komunikasi pembangunan partisipatif, (c) tingkat keberdayaan kelompok tani tidak secara langsung dipengaruhi pemanfaatan modal sosial, melainkan melalui komunikasi pembangunan partisipatif sebagai peubah mediasi.

\section{Perilaku Petani Karet}

Perilaku petani karet mencakup segala perilaku atau aktivitas yang dilakukan petani dakam berusahatani karet, yang diukur dari aspek, yaitu: pengetahuan (item 1-15) sikap (item 16-30) dan keterampilan (item 31-45). Hasil penelitian memperlihatkan bahwa perilaku petani termasuk kriteria tinggi, nilai total 10.679 rata-rata 125,77 (capaian 93,26\%). Semua indikator perilaku petani termasuk katagori tinggi, seperti pada Tabel 7.

Tabel 7. Skor Perilaku Petani Karet

\begin{tabular}{lcccc}
\hline \multicolumn{1}{c}{ Indikator } & Skor Total & Rata rata & Capaian (\%) & Kriteria Capaian \\
\hline 1. Pengetahuan & 3.659 & 42,33 & 94,09 & Tinggi \\
2. Sikap & 3.472 & 41,26 & 91,84 & Tinggi \\
3. Keterampilan & 3.548 & 42,18 & 93,85 & Tinggi \\
Skor Total & 10.679 & 125,77 & 93,26 & Tinggi \\
\hline
\end{tabular}

Keterangan: *Capaian (\%) diukur skor total/skor ideal

**Skor Ideal tiap indikator $=15$ x 3 x $84=3780$

Kriteria Capaian mengacu pada Tabel 2

Pada Tabel 7 dapat diperlihatkan indikator pengetahuan memperoleh skor 3.659 rata-rata 42,33 (94,09\%) tergolong kriteria tinggi. Artinya perilaku petani sudah baik dalam pengetahuan usahatani. Indikator kedua yaitu sikap memperoleh skor 3.472 dengan rata-rata sebesar 41,26 (91,84\%) tergolong kriteria tinggi. Artinya perilaku petani juga baik dan menunjukkan kriteria tinggi. Indikator ketiga yaitu keterampilan yang memperoleh skor 3.548 dengan rata-rata $42,18(93,85 \%)$ tergolong dalam kriteria tinggi.

Hal ini berbeda dengan penelitian Rani \& Elly ( 2013) yang menunjukkan sebagian besar petani belum penerapan teknis budidaya sesuai anjuran. Teknis budidaya itu meliputi pemupukan, pemberantasan hama penyakit, dan pemakaian zat pengatur tumbuh. Perilaku petani dalam berusahatani berkaitan dengan stabilitas harga, maka perlu usaha untuk menjamin stabilitas harga sehingga petani lebih terdorong untuk meningkatkan kualitas hasil serta produktivitasnya.

Kajian ini berbeda dengan Pratiwi \& Sudrajat (2012), yang menyebutkan bahwa dalam pengelolaan lahan pertanian, petani di Desa Sumberejo sebagian besar tergolong rendah, yaitu tidak berwawasan lingkungan. Kecenderungan perilaku petani ini dipengaruhi oleh lama pertain, usia petani, dan aktivitas penyuluhan.

\section{Produksi, Biaya Produksi, Penerimaan serta Pendapatan Petani Karet}

Jumlah produksi karet rata-rata di Kecamatan Banyuasin III $420.720 \mathrm{~kg}$ atau 420,72 ton/tahun/garapan. Petani yang mempunyai luas lahan 1,5 ha ada 4 orang jumlah produksi karetnya $15.600 \mathrm{~kg}$ /tahun/garapan. Petani yang lahannya 2 ha ada 72 orang jumlah produksinya $51.360 \mathrm{~kg} /$ tahun/garapan. Pada petani yang lahannya 3 ha produksinya $353.760 \mathrm{~kg} / \mathrm{tahun} / \mathrm{garapan}$. 
Petani karet di Kecamatan Banyuasin III, rata-rata total biaya produksinya Rp.1.674.998,018,/tahun/garapan. Biaya produksi itu mencakup penyusutan alat (hand sprayer, cangkul, parang/sabit, talang lateks, mangkok, pisau sadap, ember, cincin dan tali cincin. Biaya tetap rata-rata sebesar Rp. 330.117,066,-/tahun/ garapan, dan biaya variabel rata-rata Rp. 1.344.880,952,-/tahun/garapan. Biaya variabel ini meliputi biaya pupuk Rp. 857500,-/tahun/garapa, herbisida Rp. 120.714,29,-/tahun/garapan dan upah tenaga kerja Rp. 366.666,67,-/tahun/garapan. Penerimaan usahatani dihitung dari perkalian jumlah produksi karet dengan harga jual. Harga karet rata-rata Rp. 7.040,-/kg. Harga karet ditentukan sesuai dengan Kadar Kering Karet (K3). Petani memperoleh produksi karet rata-rata 5.008 $\mathrm{kg} / \mathrm{tahun} /$ garapan, dengan penerimaan sebesar Rp. 35.275.057,14,-/tahun/garapan. Selanjutnya pendapatan petani karet merupakan selisih penerimaan dengan biaya produksi total. Biaya produksi terdiri dari biaya tetap dan biaya variabel. Hasil analisis usahatani, yang mencakup: produksi, harga, penerinaan, biaya dan pendapatan petani karet di Kecamatan Banyuasin III diperlihatkan pada Tabel 8.

Tabel 8. Rata-rata Produksi, penerimaan, dan Pendapatan Petani Karet di Kecamatan Banyuasin III, Kabupaten Banyuasin.

\begin{tabular}{clc}
\hline No. & \multicolumn{1}{c}{ Komponen } & Usahatani Karet \\
\hline 1. & Produksi Karet $(\mathrm{Kg} / \mathrm{Thn} / \mathrm{Garapan})$ & $5.008,5$ \\
2. & Harga Karet Rata-rata (Rp/Kg) & 7.040 \\
3. & Penerimaan (Rp/Thn/Garapan) & $35.275 .057,14$ \\
4. & Biaya Total & $1.674 .998,018$ \\
& Biaya Tetap (Rp/Thn/Garapan) & $330.117,066$ \\
& Biaya Variabel (Rp/Thn/Garapan) & $1.344 .880,952$ \\
5. & Pendapatan (Rp/Thn/Garapan) & $33.600 .059,122$ \\
\hline
\end{tabular}

Dari Tabel 8. dapat dilihat pendapatan rata-rata petani karet Rp. 33.600.059,122,-/tahun/garapan. dari hasil wawancara dengan Dinas Perkebunan Kabupaten Banyuasin hal ini didukung adanya gapoktan, poktan dan aktivitas penyuluh pertanian. Di Kabupaten Banyuasin, lembaga UPPB (Unit pengolahan Pemasaran Bokar) wajib dibentuk setiap desa. Dengan dibentuknya UPPB harga jual karet diharapkan stabil penampungan. Penelitian ini didukung oleh Lopes \& Fallo (2019) yang menyatakan bahwa kegiatan usahatani padi sawah di Desa Manleen terdiri serangkaian tahapan yaitu mulai persemaian, pengolahan serta persiapan lahan, sampai panen dan pemasaran. Dari usahatani ini, penerimaan petani rata-rata $\mathrm{Rp}$ 57.889.063; Biaya produksi rata-rata Rp 12.696.538, sehingga pendapatan usahataninya rata-rata $\mathrm{Rp} 45.192 .524$.

\section{Korelasi Kinerja Gabungan Kelompok Tani dan Kinerja Kelompok Tani dengan Perilaku Petani}

Kinerja merupakan hasil kerja yang diperoleh seseorang dalam melakukan tugasnya yang didasarkan atas kemampuan, keseriusan serta pengalaman dan waktu (Hasibuan, 2001). Melalui kinerja gapoktan dan poktan dapat meningkatkan motivasi yang mampu merubah perilaku berusahatani petani karet kearah yang lebih baik. Hasil analisis dengan Korelasi Rank Spearman antara Kinerja Gapoktan (X1) dan Kinerja Poktan (X2) dengan Perilaku Petani Karet (Y) di Kecamatan Banyuasin III dapat dilihat pada Tabel 9

Tabel 9. Korelasi Kinerja Gapoktan dan Kinerja Poktan dengan Perilaku Petani Karet

\begin{tabular}{lrccc}
\hline No. & Variabel & Koefisien Korelasi & Sig. (2-tailed) & Hubungan \\
\hline 1. & X1 dengan Y & $0,340^{* *}$ & 0,002 & Sangat signifikan \\
2. & X2 dengan Y & $0,374^{* *}$ & 0,000 & Sangat signifikan \\
\hline
\end{tabular}

Keterangan :

Y : Perilaku petani karet

X1 : Kinerja Gapoktan

X2 : Kinerja Poktan

Dari Tabel 9 diketahui bahwa hubungan yang sangat signifikan antara Kinerja Gapoktan (X1) dengan Perilaku $(\mathrm{Y})$ dengan nilai Rs=0,340**. Juga terdapat korelasi yang sangat signifikan antara Kinerja Poktan (X2) dengan Perilaku (Y) dengan nilai Rs $=0,374 * *$. Ini berarti variasi tingkat perilaku petani bisa dijelaskan melalui tingkat kinerja gapoktan sebesar $34 \%$, dan secara parsial dapat dilelaskan pula bahwa variasi tingkat perilaku petani dapat dijelaskan oleh tingkat kinerja poktan sebesar $37,4 \%$. 
Mengacu interpretasi nilai korelasi Rank Spearman (Sugiyono, 2009) menunjukkan korelasi kinerja gabungan kelompok tani (X1) dengan perilaku petani (Y) serta kinerja kelompok tani (X2) dengan perilaku petani (Y) termasuk katagori cukup kuat, sedangkan nilai positif koefisien korelasi kedua variabel mengindikasikan korelasi searah antara kinerja Gapoktan serta Poktan dengan perilaku petani. Hal ini dapat diartikan bahwa jika kinerja Gapoktan dan Poktan semakin baik maka perilaku petani semakin baik pula. Hal ini sejalan dengan Ramainas \& Pasaribu (2015) yang menunjukkan terdapat korelasi signifikan, cukup kuat (korelasi Pearson 0,626) antara kelompok tani dengan perilaku masyarakat petani.

Melalui analisis korelasi Rank Spearman tersebut diketahui bahwa antara kinerja gapoktan serta poktan dengan perilaku petani karet terdapat korelasi yang cukup kuat. Hal ini ditunjukkan oleh peran Gapoktan sebagai unit usahatani/produksi, unit usaha sarana dan prasarana produksi, unit pengolahan, unit pemasaran, unit keuangan mikro, serta peran kelompok tani sebagai unit produksi, kelas belajar, dan wahana kerja sama. Peran gapoktan sangat penting bagi hasil pemasaran karet yakni berperan membuka lelang karet pada UPPB. Sementara poktan sangat penting kaitannya dengan kegiatan penyuluhan yakni sebagai kelas belajar karena penyuluh pertanian yang memberikan pembelajaran melalui kelompok tani, baik berupa materi ataupun praktek langsung. Tingkat kinerja yang tinggi baik gapoktan maupun poktan, di Kecamatan Banyuasin III, akan mendorong usahatani karet semakin efektif dan efisien, yang pada gilirannya akan meningkatkan produksi serta pendapatan petani.

\section{Hubungan antara Perilaku Petani dengan Produksi serta Pendapatan}

Dalam melakukan usahatani, pendapatan adalah hasil akhir diharapkan petani. Tingkat pendapatan petani ditentukan oleh produksi, biaya produksi, dan harga jual produk. Sementara perilaku petani menjadi faktor penentu yang memungkinan terjadinya proses produksi usahatani. Perilaku petani yang ideal, kreatif, inovatif mencerminkan kemandirian petani. Hasil analisis dengan Uji korelasi Rank Spearman hubungan antara perilaku petani karet (Y) dengan produksi (Y1) dan pendapatan (Y2) di Kecamatan Banyuasin III terlihat pada Tabel 10.

Tabel 10. Korelasi Perilaku Petani dengan Produksi serta Pendapatan Petani Karet di Kecamatan Banyuasin III

\begin{tabular}{llccc}
\hline & Variabel & Koefisien Korelasi & Sig. (2-tailed) & Hubungan \\
\hline 1. & Y dengan Y1 & $-0,032$ & 0,775 & Tidak signifikan \\
2. & Y dengan Y2 & $-0,070$ & 0,528 & Tidak signifikan \\
3. & Y1 dengan Y2 & $0,967^{* *}$ & 0,000 & Sangat signifikan \\
\hline
\end{tabular}

Keterangan:

Y : Perilaku petani karet

Y1 : Produksi

Y2 : Pendapatan

Berdasarkan Tabel 10 dapat dijelaskan bahwa tidak terdapat korelasi yang signifikan (dengan $\alpha=0.05$ ), antara perilaku petani (Y) dengan dengan produksi (Y1) dengan nilai Rs $=-0,032$ dan korelasi dengan pendapatan (Y2) dengan nilai $\mathrm{Rs}=-0,070$.

Kondisi ini (tidak terdapatnya hubungan antara perilaku dengan produksi dan pendapatan petani) dapat dijelaskan melalui kondisi perilaku petani yang mencakup pengetahuan, sikap dan keterampilan. Data penelitian dikumpulkan pada bulan Agustus 2020 di masa pamdemi covid 19. Hal ini mempengaruhi pada perilaku masyarakat, khususnya petani di lokasi penelitian. Pada masa pandemic petani tidak melakukan pemupukan sehingga produksi berkurang. Padahal sebaiknya tanaman karet dipupuk 2 kali dalam setahun. Agar hasil meningkat (tinggi) tanaman karet perlu dilakukan perawatan yang baik. Pada masa pandemi, umumnya petani tidak melakukan perawatan yang maksimal dan ini berarti biaya yang dikeluarkan relatif sedikit, sehingga pendapat mereka cenderung lebih tinggi, karena berkurangnya biaya. Kajian ini selaras dengan penelitian Dalimunthe \& Murdianto (2013) yang menyatakan bahwa tidak ada hubungan positif signifikan antara implementasi LKM dengan tingkat pendapatan pelaku usaha mikro. Hal ini disebabkan oleh rendahnya tingkat pendapatan pelaku usaha mikro.

Dari Tabel 10 juga dapat dilihat terdapat korelasi sangat signifikan $(\alpha=0.01)$ antara Produksi (Y1) dengan Pendapatan (Y2), dengan nilai Rs $=0,967^{* *}$. Mengacu pada interpretasi nilai korelasi Rank Spearman (Sugiyono, 2009) mengindikasikan tingkat korelasi yang sangat kuat antara produksi (Y1) 
dengan pendapatan petani (Y2). Nilai Rs $=0,967$ menunjukkan bahwa 96,7 \% variasi tingkat pendapatan dapat dijelaskan oleh variasi produksi. Demikian juga dapat diartikan bahwa semakin tinggi produsi maka semakin tinggi pula pendapatan petani.

Penelitian ini sejalan dengan Damanik (2013) yang menujukkan kan bahwa pendapatan petani padi di Kecamatan Masaran secara positif signifikan dipengaruhi oleh luas lahan, jumlah tenaga kerja, dan biaya produksi secara bersama-sama, dengan Nilai R2 $=0,975$. Hal ini berarti bahwa 97,5 persen pendapatan petani dipengaruhi oleh jumlah tenaga kerja, biaya produksi dan luas lahan, dan sisanya 2,5 persen dipengaruhi faktor lain. Secara parsial luas lahan (X1) dan biaya produksi (X3) berpengaruh positif dan signifikan, sementara jumlah tenaga kerja (X2) tidak berpengaruh signifikan.

Hasil kajian ini juga sama dengan Mamondol \& Sabe (2016) yang menyatakan bahwa untuk luas lahan kurang 0,5 ha penerimaan rata-rata petani $\mathrm{Rp}$ 4.053.160/MT, dengan rata-rata biaya produksi $\mathrm{Rp}$ 3.302.599,33/MT, dan rata-rata pendapatan Rp 750.560,67/MT. Untuk petani yang luas lahannya 0,51 ha, rata-rata penerimaan Rp 11.892.624/MT biaya produksi rata-rata Rp 7.579.606,60/MT, dengan pendapatan rata-rata $\mathrm{Rp} 4.313 .017,40 / \mathrm{M}$. Petani yang luas lahannya lebih 1 ha penerimaannya $\mathrm{Rp}$ 25.803.240/MT, dan biaya produksi rata-rata Rp 14.831.693,67/MT dan pendapatan rata-rata Rp 10.971.546,33/MT. Luas lahan berkorelasi positif signifikan dengan penerimaan, biaya produksi, dan pendapatan usahatani. Penambahan luas lahan mengakibatkan kenaikan biaya produksi, penerimaan serta pendapatan. Meski begitu, bertambahnya luas lahan dapat meningkatkan biaya produksi yang lebih besar dari pada bertambahnya pendapatan. Hal ini menunjukkan terjadi inefisiensi pada kegiatan usahatani. Hal serupa terdapat pada penelitian Tomy (2013), yakni pendapatan petani dari usahatani jagung sebesar Rp 2.829.697/ha.

\section{KESIMPULAN}

Tingkat kinerja gabungan kelompok tani tergolong tinggi (capaian 98,00\%) dan kinerja kelompok tani tergolong tinggi (capaian 93,73) artinya kinerja gapoktan dan poktan sudah maksimal. Perilaku petani tergolong tiggi $(93,26 \%)$, produksi karet rata-rata petani 5,008 ton/tahun/garapan), serta pendapatan rata-rata petani karet (Rp. 33.600.059,122- tahun/garapan). Terdapat korelasi sangat signifikan antara kinerja gapoktan dan poktan dengan perilaku petani karet, dengan nilai koefisien korelasi Rank Spearman $(\mathrm{Rs})=0,340$ dan 0,374 pada $\mathrm{a}=0,01$. Sementara tidak terdapat korelasi antara perilaku dengan produksi dan pendapatan petani karet, dengan nilai koefisien korelasi Rank Spearman (Rs) = masing-masing 0,032 dan $-0,070$. Terdapat hubungan sangat signifikan antara produksi dan pendapatan petani dengan nilai $\mathrm{Rs}=0,967$ pada $\mathrm{a}=0,01$.

\section{UCAPAN TERIMA KASIH}

Terima kasih kepada Universitas Sriwijaya yang telah memberikan bantuan dana Penelitian Hibah Profesi Tahun 2019 Lembaga Penelitian dan Pengabdian kepada Masyarakat. Terima kasih juga disampaikan kepada seluruh petani karet sebagai responden, informan, serta Ketua Gapoktan dan Poktan yang telah memugkinkan terlaksananya penelitian ini.

\section{DAFTAR PUSTAKA}

BPS, K. B. (2017). Perkebunan Karet Rakyat Menurut Kecamatan di Kabupaten Banyuasin 2017.

Dalimunthe, N. C. J. M. (2013). Analyzing The Implementation of LKM Posdaya Kenanga to Micro Entrepreneur Income Level in Situ Gede Village. Jurnal Penyuluhan, 9(2).

Damanik, J. aman. (2013). Analisis Faktor-Faktor yang Mempengaruhi Pendapatan Petani Padi Di Kecamatan Masaran, Kabupaten Sragen. 2(4), 446-455.

Demmallino, Eymal B, Rahmadanih, A. (2018). Efektivitas Kinerja Organisasi Gabungan Kelompok Tani POttanae. Jurnal Sosial Ekonomi Pertanian, 14(3), 285-296.

Fatchiya, A., \& Hernanda, T. (2015). The Level Of Agri-Extension Worker Performance in South Ogan Komering Ulu (OKU) District. Jurnal Penyuluhan, 11(1), 79-90.

Hadi, S., Akhmadi, A. N., \& Prayuginingsih, H. (2019). Peran Kelompok Tani dan Persepsi Petani terhadap Penerapan Budidaya Padi Organik di Kabupaten Jember Role of Farmers ' Groups and Farmers 'Perception in Promoting Its Members against Application of Organic Rice Cultivation in District of Jember Petani di. 15(2), 154-168.

Hasibuan, M. (2001). Manajemen Sumber Daya Manusia : Pengertian Dasar,Pengertian, dan Masalah. PT.Toko Gunung Agung. 
Indrawati, N. N. (2016). Fungsi Gabungan Kelompok Tani (Gapoktan) Bagi Petani Desa Pojokkulon Kecamatan Kesamben Kabupaten Jombang. AntroUnairdotNet, 5(2), 335-348.

Jaya, M. nur, Sarwoprasodjo, S., Hubeis, M., \& Sugihen, B. G. (2017). Tingkat Keberdayaan Kelompok Tani pada Pengelolaan Usahatani Padi di Daerah Istimewa Yogyakarta, Jawa Tengah. Jurnal Penyuluhan, 13(2), 166-180. https://doi.org/10.25015/penyuluhan.v13i2.15903

Lopes, T., \& Fallo, Y. M. (2019). Analisis Produksi Dan Pendapatan Usahatani Padi Sawah Di Desa Manleten Kecamatan Tasifeto Timur Kabupaten Belu. Agrimor, 4(1), 9-12. https://doi.org/10.32938/ag.v4i1.616

Mamondol, M R; Sabe, F. (2016). The Effect of Land Size on Revenue, Cost Production , and Income of Rice Field Farming at Toinasa Village West Pamona District. Jurnal Envira, 1, 48-59.

Muhammad, N. (2016). Hubungan Faktor Internal Dan Eksternal Program Puap Di Kabupaten Lombok Timur Dosen Fakultas Pertanian - Universitas Gunung Rinjani. Journal Ilmiah Rinjani, 3, 69-77.

Mujiburrahmad, Muljono, P., Sadona, D. (2014). Performance Agricultural Extension in Pidie District of Aceh Province to Implement Tasks and Functions. Jurnal Penyuluhan, 10(2), 141-150.

Pratiwi, E. R., \& Sudrajat. (2012). Perilaku Petani dalam Mengelola Lahan Pertanian di Kawasan Rawan Bencana Longsor (Studi Kasus Desa Sumberejo Kecamatan Batur Kabupaten Banjarnegara Jawa Tengah). Jurnal Bumi Indonesia, 1(3), 355-362.

Ramainas, \& Pasaribu, A. (2015). Perilaku Masyarakat Petani Terhadap Penumbuhan Kelompoktani di Kecamatan Sorkam Barat. Jurnal Agrica Ekstensia, 9(2), 37-46.

Rani Andriani Budi Kusumo, Elly Rasmikayati, G. W. M. (2013). Perilaku Petani dalam Usahatani Mangga Di Kabupaten Cirebon. Journal of Chemical Information and Modeling, 53(9), 16891699.

Ridwan dan Akdon. (2007). Rumus dan Data dalam Analisis Statistika. Alfabeta.

Ruslan, R. (2006). Manajemen Public Ralation dan Media Komunikasi, Konsepsi dan Aplikasi. PT. Raja Grafindo Persada.

Safe'i, R., Febryano, I. G., \& Aminah, L. N. (2018). Effect of the existence gapoktan to farmer income and land cover change in community forest. Sosiohumaniora-Jurnal Ilmu-Ilmu Sosial dan Humaniora, 20(2), 109-114.

Sihotang, R. J., Arsyad, A., \& Masithoh, S. (2019). Analisis Kinerja Gapoktan Berdasarkan Tingkat Kepuasan Anggota Dan Karyawan. Jurnal Agribisains, 5(1), 13. https://doi.org/10.30997/ jagi.v5i1.2167

Soekartawi. (2002). Analisis Usaha Tani. UI-Press.

Sriati, Hakim,N.,Arbi, M. (2017). Partisipasi Petani dan Efektivitas Gapoktan dalam Penguatan Lembaga Distribusi Pangan Masyarakat (LDPM) di Kecamatan Makarti Jaya Kabupaten Banyuasin. Jurnal Pen. Jurnal Penyuluhan, 13, 88-96.

Sriati. (2012). Metode Penelitian Sosial. Unsri Press.

Sugiyono. (2009). Metode Penelitian Pendidikan Pendekatan Kuantitatif, Kualitatif, dan R\&D. Alfabeta.

Tampubolon, M. A. C., Supriana, T., \& Shombing, L. (2013). Analisis Tingkat Pendapatan Petani Karet Rakyat Berdasarkan Skala Usaha Minimum (Studi Kasus: Desa Naman Jahe, KEcamatan Salapian, Kabupaten Langkat). Fakultas Pertanian, Universitas Sumatera Utara, Medan, 1, 1-13.

Tomy, J. (2013). Analysis of Corn Production and Income Farming at Palolo Subdistrict Sigi Regency. Jurnal Agroland, 20(2), 146-154. 